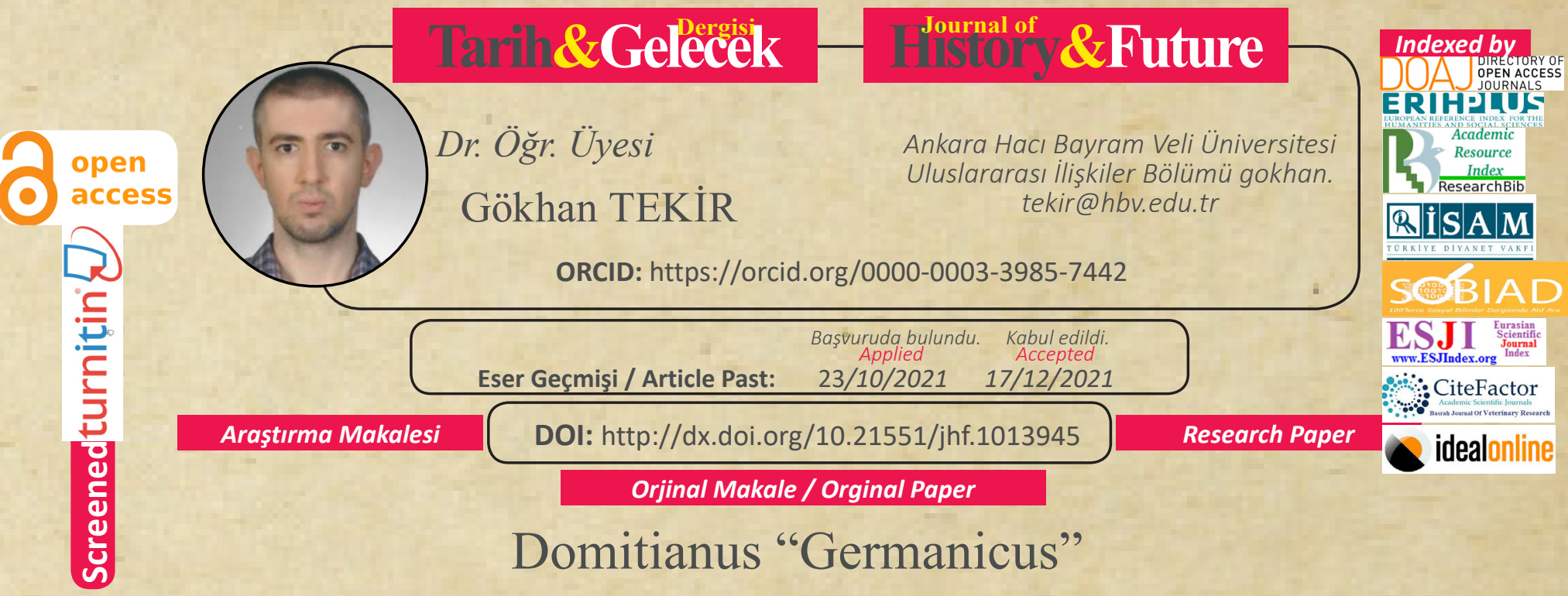

\title{
Domitianus "Germanicus"
}

\section{Abstract}

Domitian, the last Flavian emperor, placed Germania at the center of his foreign policy. His first military campaign was against the Chatti, which comprised the most dangerous armed forces among German tribes. After neutralizing them, Domitian had extended the frontiers of the Roman Empire in Germania. He made administrative reforms for newly acquired territories, making Roman presence longlasting. He also gradually expanded Rome's rule in Germania during his rule. After successfully dealing with the Dacians and subduing them on the Danube frontier, he refocused his attention other German tribes the Marcomanni and the Quadi. While preparing a pincer movement against the Marcomanni and the Quadi and their Sarmatian allies by establishing diplomatic contacts with several tribes in the region and concentrating military forces, he was assassinated in Rome. Had he not been assassinated, the Roman Empire's expansion into Central Europe could have been achieved. Yet, his successes in Germania rightly earned Domitian the cognomen Germanicus,

Keywords: Domitian, Germania, Germanicus, the Chatti, Roman Empire

\section{$\ddot{O} z$}

Domitian, son Flavian imparatoru, Germania bölgesini dış politikasının merkezine koymuştur. İlk askeri harekatı Alman kabilelerinin en tehlikeli askeri güçlerini oluşturan Chatti kabilesine karşı olmuştur. Onları etkisiz hale getirdikten sonra, Domitian Roma İmparatorluğu'nun sınırlarını Germania'da genişletmiştir. Yeni ele geçirilen alanlarda idari reformlar yaparak Roma yerleşimini uzun vadeli olmasını sağlamıştır. Yönetimi sırasında Roma yönetimini kademesel olarak arttırmıştır. Tuna sınırında Daçyalılarla başarılı bir şekilde mücadele edip onlara boyun eğdirdikten sonra dikkatini Marcomanni ve Quadi gibi Alman kabilelerine tekrar yoğunlaşmıştır. Marcomanni ve Quadi'lere karşı ve onların Sarmatyalı müttefiklerine karşı bir huruç harekatı planlarken Roma'da suikaste uğramıştır. Eğer suikaste uğramasaydı Roma İmparatorluğu sınırlarını genişletmesi Orta Avrupa'ya kadar sağlanabilecekti. Yine de Germania'daki başarıları Domitian'a Germanicus takma adını haklı bir şekilde kazandırmıştır.

Anahtar Kelimeler: Domitian, Germania, Germanicus, Chatti, Roma İmparatorluğu 


\section{Inroduction}

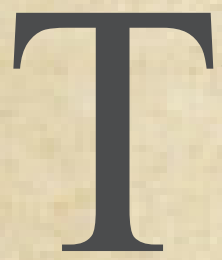

he era of last Flavian emperor Titus Flavius Domitian had been blackened by historians who belong to senatorial class, whose privileges and authority had been curtailed by the authoritarian emperor. However, the $20^{\text {th }}$ century has witnessed the rehabilitation of this misrepresented emperor. Although the modern historians praised Domitian's administrative and financial efficiency, Domitian's successes in foreign policy should also be emphasized.

Germania had been centered on Domitian's foreign policy. He correctly identified the biggest threat emanated from Germania. His first campaign was against Germania's one of the most formidable tribes, the Chatti. His victory over this tribe earned him cognomen Germanicus. He relocated troops from Britannia to Germany to stabilize the frontier. Domitian created a new legion called Legio I Minervia to further security in the area. In the last years of Domitian focused on wars with the Marcomanni and the Quadi tribes, even foregoing a decisive victory against the Dacians to avoid war in two fronts. He supplied many legions to the area for a decisive offensive in Central Europe immediately before his assassination. His successors Nerva and Trajan, on the other hand, abandoned this plan for a campaign against the Dacians. Although Trajan gained a glorious victory against the Dacians, this success was not strategically long-term. Starting from Hadrian era the emperors gradually withdrew from Dacia. Later emperors especially in the second half of the first century had to deal with the Marcomanni and the Quadi. Had Domitian not been assassinated, the composition of the Central Europe could have been very different.

Domitian not only employed military means for Germania but also administrative and diplomatic measures. Administratively, he created two provinces: Upper Germania and Lower Germania. Diplomatically, he established contacts with several German tribes to gain foothold in the region and to prevent them becoming allies of the Marcomanni and the Quadi. These measures demonstrate the multiple dimensions of Domitian's Germania policy.

This article aims to analyze Domitian's Germania campaigns, his administrative and diplomatic policies. Although the classical authors such as Tacitus, Cassius Dio and Suetonius underestimated Domitian's Germania victories, Domitian followed a consistent and sound strategies in Germania. Domitian's campaigns in his last years against the Marcomanni and the Quadi were far from decisive. Yet, he was planning a big campaign without haste against these tribes to root out the problem once and for all. However, his predecessors busied themselves with easy and glorious but strategically unimportant campaigns against the Dacia. This strategic mistake cost the Roman Empire dearly especially during Marcus Aurelius' reign, which witnessed a huge conflict with the Marcomanni. Domitian's strategic insight in recognizing and planning to deal with these tribes, therefore, needs to be praised and admired.

\section{Germania from Augustus to Domitian}

Caesar's conquest of Gaul caused direct confrontation of the Roman Empire and the Germanic tribes. After series of civil wars, when Augustus assumed absolute power in 27 
B.C., the Rhine frontier was his focus. In 20-19 B.C., he sent his right-hand man, Agrippina, to Gaul to improve road networks. In 16 B.C. a group consistent of the Sugambri, Usipetes, and Tencteri tribes executed Roman soldiers in the east of the Rhine and crossed the river. This group encountered legion commanded by Marcus Lollius, defeated it, and captured its eagle standards. Augustus personally went to Gaul to prepare Roman troops for the campaign across the Rhine, remaining there between 16-13 B.C. His stepson and future emperor Tiberius accompanied him. ${ }^{1}$ By that time, Tiberius and his brother Drusus had conquered Raetia. ${ }^{2}$ Drusus was entrusted to carry out the subjection of German tribes. He successfully accomplished his task by leading troops across the Rhine and waging wars against German tribes. However, he fell from his horse and died in 9 B.C. Tiberius picked up the war where Drusus left. He traversed every part of Germany and subdued the region. Germania was almost reduced to the status of a tributary province. ${ }^{3}$ The assessment of Velleius Paterculus is important because the successes of Drusus and Tiberius might have led Augustus to think that the military subjugation of Germania was completed. When Tiberius had to leave the region due to Pannonian rebellion, ${ }^{4}$ the choice of Varus as commander by Augustus reflects this complacency.

As Augustus though that the area between the Rhine and Elbe had been conquered, the next task was to introduce provincial administration. Therefore, Varus must have interpreted his mission was to create Roman administrative structures such as censor taking and taxation. ${ }^{5} \mathrm{He}$ did not keep his legions together, a sensible approach in a hostile region. Instead, he distributed them to deal with robbers or other petty duties. He fraternized with the leaders of German tribes, Arminius and Segimerus who actually began conspiring against him. At the day of the ambush, he was proceeding towards the enemy territory without caution as he was in a friendly country. ${ }^{6}$ The Roman legions under Varus' command were ambushed at Teutoburg Forest. Three legions, as many as cavalry divisions, and six cohorts were slaughtered. ${ }^{7}$ When the news of disaster reached to Rome, Augustus did not cut his hair and did not shave his beard for a long time. He dashed his head against the wall and screamed: "Quintilius Varus, give me back my legions." not only psychological. Augustus expected that German tribes were going to invade Gaul and Italy. He began preparations by forcing men to enroll the army. He entrusted Tiberius to deal with German threat. ${ }^{9}$

After subduing the revolts in Pannonia and Illyria, the empire's most talented general once again was called to save the empire. Drawing lessons from Varus' mistakes, Tiberius

\footnotetext{
1 Peter S. Wells, The Battle That Stopped Rome (New York and London: W. W. Norton \& Company, 2003), 77.

2 Vell.Pat.II.95.1

3 Vell.Pat.II.97.1-4.

$4 \quad$ Vell.Pat.II.98.1

5 Wells, p. 84.

6 Cass.Dio.LVI.19.1-5.

$7 \quad$ Vell.Pat.II.117.1

8 Suet.Div.Aug.XXIII.

9 Cass.Dio.LVI.23.1-3.
} 
conducted his campaigns in Germania prudently. As Rome did not have luxury to spare even one soldier after Varus' loss, Tiberius adopted a slow but cautious approach. He crossed the Rhine to destroy supply lines of German tribes by ravaging crops, burning dwellers, and dispersing the inhabitants. ${ }^{10}$ While conducting his campaigns he required strict discipline, he even demeaned a commander of a legion when this commander set up a hunting expedition with a few soldiers. ${ }^{11}$ Tiberius made himself accessible to his subordinates and commanded them to consult him on every issue. He even slept in an open tent to be aware of any sudden emergency. ${ }^{12}$ Even after he achieved stabilization, he did not cross the Rhine unless German tribes crossed, knowing that his presence on the other side of the Rhine would prevent them from crossing. ${ }^{13}$ Germanicus, the son of Tiberius' deceased brother Drusus, joined him in his campaign. Together they crossed the Rhine and celebrated Augustus' birthday by holding horse races, but they did not engage in any war. ${ }^{14}$ This celebration had a symbolic meaning that the region was stabilized.

Tiberius returned to Rome and Germanicus stayed in Germania to oversee the region. ${ }^{15}$ When Augustus died, Tiberius assumed princes as an adopted son and chosen successor of Augustus. There was a trick, though. He was forced to adopt his nephew Germanicus, who was married to Augustus' granddaughter Agrippina. As soon as Tiberius acceded the emperorship, two revolts erupted on the Danube and on the Rhine. The revolt on the Danube occurred due to the troops' grievances concerning the pay and term of service, the revolt on the Rhine had political character. The mutiny on the Danube was suppressed by Tiberius' son Drusus. ${ }^{16}$ The mutiny on the Rhine, however, aimed to elevate Germanicus into emperorship. There were two armies with four legions. Germanicus was away, collecting the taxes when the revolt broke. However, Germanicus did not accept the troops' offer and quelled the revolt. ${ }^{17}$ This revolt was the first event that the involvement of the troops in seeking to place an emperor.

Germanicus, soon, abandoned Tiberius' cautious Germania strategy by launching an offensive across the Rhine. In AD 15 Germanicus crossed the Rhine with eight legions. He divided his army by assigning four legions to his legate Caecina. Germanicus himself charged against the Chatti, catching them in surprise. Caecina was deputed to deal with the Cherusci tribe. The first phase of the expedition was successful. However, Arminius managed to draw the Roman Army deeper into the woods, planning to ambush the Roman legions as he did in AD 9. Germanicus proved himself to be more skillful than Varus and escaped from the ambush. ${ }^{18}$ The goals of this expedition are controversial for historians. Germanicus might have sought relief for the mutineer legions by canalizing their energy to

10 Robert Seager, Tiberius (Malden: Blackwell Publishing, 2005), 36.

11 Suet.Tib.19.1

12 Suet.Tib.18.2

13 Cass.Dio.LVI.24.6.

14 Cass.Dio.LVI.25.3.

15 Vell.Pat.II.123.1

16 Seager, p. 52.

17 Tac.Ann.1.31-34.

18 Tac.Ann.1.55-70. 
Germania. Another view suggests that Germanicus shared Augustus' view that the region between the Rhine and the Elbe should be incorporated into the Roman Empire. Tiberius, however, did not share his hopes, worrying about the hostile tribes and difficult terrain of the area. ${ }^{19}$ The results of the expedition were inconclusive. The troublesome tribes in Germania remained at large.

In $\mathrm{AD} 16$, although surprise factor vanished and the previous year's expedition cost men and money, Germanicus pressed another expedition in Germania. Despite some considerable successes such as capturing the wife of Arpus, the leader of the Chatti, the rest of the Chatti managed to escape. ${ }^{20}$ Germanicus also prevailed over the Cherusci, the tribe of Arminius, but the fleets, which carried the troops' supplies were sunk due to the storm. ${ }^{21}$ That gave hope to the Germans, but Germanicus and his legate Silius managed to keep the enemy at check. Not willing to risk camping in the winter in Germania, Germanicus crossed back to the Rhine. While retreating, he pillaged and destroyed the German villages. ${ }^{22}$ Germanicus asked another permission for an expedition from Tiberius, but the emperor had enough. He reminded the costs that brought by these expedition and advocated diplomacy instead of force. Tiberius, however, offered Germanicus consulship, whose requirements required Germanicus' presence in Rome and recalled him. ${ }^{23}$

Despite the relative successes of Germanicus' expeditions, the price of these successes was too heavy. These heavy costs did not bring decisive victory. The decisive victory could be achieved by destroying German manpower of the troublesome tribes and the permanent presence of Roman forces on the eastern side of the Rhine. These goals at that time could not be achieved with yearly expeditions. The presence of the Roman troops on the western side of the Rhine was a deterrent factor for the German tribes, which intent to cross the Rhine. Tiberius was aware of that fact. If it had been up to Tiberius, he would not have sanctioned Germanicus' expeditions. It was Augustus, who appointed Germanicus to Germania. Tiberius did not want to change the commanding place of Germanicus, who suppressed the mutineers on the Rhine. Tiberius even granted Germanicus a degree of authority in conducting the war, but Germanicus' persistence in pursuing the war despite costs must have awakened Tiberius' suspicion regarding Germanicus' political. Finally, Tiberius managed to interrupt the war skillfully by granting Germanicus a consulship. ${ }^{24}$

The end of Germanicus' campaign did not mean the end of the Roman engagement. As Tiberius had mentioned to Germanicus, the diplomatic course was followed. The tribes were played with each other to break grand coalitions against Rome. For instance, Vannius, the chief of the Quadi tribe was encouraged to wage war against the Marcomanni led by Maroboduus ${ }^{25}$. Another factor which loosened the resolve of grand coalitions against the Romans is the withdrawal of the Roman forces from the eastern part of the Rhine.

19 David Shotter, Tiberius Caesar (London and New York: Routledge, 2004), 58.

20 Tac.Ann.2.7.

21 Tac.Ann.2.23.

22 Tac.Ann.2.25.

23 Tac.Ann.2.26.

24 Seager, pp. 73-74.

25 Barbara Levick, Tiberius The Politician (New York: Routledge, 1999), 113. 
When the Romans withdrew, the various tribes turned against the leaders of the coalitions. Maroboduus, the king of the Marcomanni was overthrown by his rivals and sought refuge in Rome. ${ }^{26}$ Arminius, who inflicted one of the worst defeats to Rome, was poisoned by his own men, who feared his autocratic tendencies. ${ }^{27}$ Thus, we can conclude that Tiberius saw the bigger picture in Germania by following a sound strategy in Germania.

Another unliked emperor by the Senate, Gaius, who was the son of Germanicus, also planned an expedition for Germania after the discovery of conspiracy of his sisters to overthrow and kill him. Gaius most probably wanted to stabilize the army as the army was the most powerful source of his power. His departure in November made the expedition on right side of the Rhine impossible. He got acquainted with the troops there and imposed discipline among them. It is apparent that several military engagements occurred in late AD 39 and Gaius was saluted as emperor by the troops. ${ }^{28}$ Suetonius narrates an intriguing passage concerning the activities of Gaius in Germania. He hid his German bodyguards in the forest, he pretended that he received news that the enemy was close at hand. He marched his friends to find the supposed enemy and rebuked them who did not follow the troops, presenting his followers with crowns. He played different versions of this game during the expedition. ${ }^{29}$ Although Suetonius distorts these events as examples of his insanity, these were clearly military exercises. Gaius wanted to keep troops discipline and ready for the possible incursions from Germania. This indicates Suetonius' bias concerning emperors disliked by the senate.

Claudius did not engage in conquest in Germania, limiting his engagement with the region by responding disturbances among German tribes. ${ }^{30}$ Germania did not provide any triumphs between AD17-AD 83. ${ }^{31}$ Yet, the Roman legions in the region played an important role in Roman politics. In the year of four emperors, AD 69, Vitellius was proclaimed emperor by the legions on the Rhine. He successfully defeated Otho and became emperor. He also took cognomen Germanicus, ${ }^{32}$ although he did not gain any victory against German tribes. Therefore, the Rhine legion played role in Rome's domestic politics as well as foreign policy.

\section{Domitian's Ascendancy to Power}

Titus Flavius Domitian was the younger son of the emperor Vespasian, who became the emperor in A.D 69. In that year, unlike his father Vespasian and his older brother Titus, who were in the campaign in Jerusalem, he was in Rome. After Vespasian declared himself emperor by his legions, Domitian was the foremost target of reigning emperor

26 Tac.Ann.2.63.

27 Tac.Ann.2.88.

28 Aloys Winterling, Caligula: A Biography (Berkeley Los Angeles London: University of California Press, 2011), 113.

29 Suet.Gaius.45.1-2.

30 Barbara Levick, Claudius (London: B. T. Batsford Ltd., 1990), 151.

31 Levick, Claudius, p. 152.

32 Suet.Vit.9.2. 
Vitellius. When the legions, which supported Vitellius approached Rome, he was targeted by Vitellius' assassins. He hid himself as an Isis devotee to escape them. After the victory, he was hailed as Caesar and became the nominal head of Vespasian forces until his father Vespasian arrived in Rome next year. ${ }^{33}$

When Vespasian arrived in Rome, Domitian's position changed from superior to superfluous. Although he participated in ceremonial events, his position was shadowed by his emperor father and his popular older brother Titus. ${ }^{34} \mathrm{He}$ held the title Caesar, Princeps Iuventutis, and various priesthoods. ${ }^{35}$ Yet, Titus was the heir apparent and became emperor in AD 79 when Vespasian died. Despite not being officially announced, Domitian was the heir presumptive. Unexpectedly, Titus died when he was 42 years old, and Domitian became the emperor. ${ }^{36}$

\section{Domitian's Chatti Campaign}

The Chatti were one of the most formidable Roman enemies in Germania. They live in Kassel and Fritzlar, north of Taurus modern Hesse. In AD 50, the Chatti attacked Mainz and Pomponius Secundus quelled them. In AD 69 they attacked Mainz again, but they were not successful. ${ }^{37}$ The Chatti had previously collaborated with the Cherusci against Rome and Germanicus attacked them in his campaigns. They were principal foreign opponents of Domitian in his first decade of reign. Tacitus describes them as:

For Germans they have a great deal of judgement and shrewdness. They elect their leaders and obey their orders; they can keep their ranks together and recognize an opportunity or postpone their attack. They plan their daytime routine and construct defences for the night; they reckon fortune to be fickle but they depend on courage; and, what is rarest of all, and is owed to their judgement and discipline, they put more trust in their general than in their army. All their strength lies in their infantry, which, as well as carrying arms, is burdened by tools and provisions as well. You may see other peoples going out to battle, the Chatti to wage war. They rarely engage in sudden forays or chance encounters. ${ }^{38}$

This description categorizes the Chatti as an organized army instead of an ambushing tribe. Thus, Domitian was right to watch closely their activities of the Rhine.

The hostile sources such as Suetonius, Tacitus, and Cassius Dio evaluate Domitian's campaign against Chatti and his victory in Germania with derision. Suetonius suggested that Domitian's expedition in Germania was "uncalled for" and his main goal was to gain glory. ${ }^{39}$ Cassius Dio claimed that Domitian waged wars against the tribes beyond the Rhine

Suet.Dom.1.1-4.

34 Pat Southern, Domitian the Tragic Tyrant (Oxon: Routledge, 1997), 24.

35 Brian Jones, The Emperor Domitian (London and New York: Routledge, 1992), 19.

36 Suet.Titus.11.1

37 Southern, p. 82.

38 Tac.Ger.30.

39 Suet.Dom.2.1. 
that enjoy treaty rights. ${ }^{40}$ Tacitus also said that Domitian's victory against the Chatti was a sham. ${ }^{41}$ Among these reviews Cassius Dio's and Tacitus' are particularly interesting. Cassius Dio even protects and excuses the Chatti tribe and found Domitian guilty. Tacitus contradicts with himself. He demonstrates the formidable nature of the Chatti by pointing out their disciplined army structure in his book Germania but also claims that victory against them is a sham in his other book Agricola.

The impartial assessment came from Frontinus, the soldier and bureaucrat, who served to the Roman Empire during Vespasian, Titus, Domitian and Trajan's reigns:

When the Emperor Caesar Domitianus Augustus Germanicus wished to crush the Germans, who were in arms, realizing that they would make greater preparations for war if they foresaw the arrival of so eminent a commander himself, he concealed the reason for his departure from Rome under the pretext of taking a census of the Gallic provinces. Under cover of this he plunged into sudden warfare, crushed the ferocity of these savage tribes, and thus acted for the good of the provinces. ${ }^{42}$

Even after Domitian's assassination and damnatio memoriae by the Senate, under the new administration, Frontinus did not retract his praise on Domitian so we can consider his statements are closer the truth. This passage reflects important conclusions. Frontinus states that "the Germans who were in arms." Therefore, it was the Chatti, who prepared to attack the Roman Empire. Domitian acted to defend the frontiers instead of boasting his popularity as Suetonius suggested. This passage also refutes Cassius Dio's argument that Domitian violated peace that exist between the Chatti and the Roman Empire. Secondly, Domitian was aware of the power of the Chatti. He prepared the war very seriously, concealing his strategy before his counter-offensive against the Chatti.

Domitian conducted his operations in Germania in a vigorous manner. The frontier that Domitian dealt with was 120 miles long. He built military roads that penetrated into a wooded and broken territory. Thus, he secured immunity to the Roman troops and opened access to the fortresses of the Chatti. These fortresses were massive structures with ramparts of stone and timber. The operations, therefore, required the participation of several legions. Domitian created Legio I Minervia and located this legion to Bonn. Thus, I Rapax was freed to join operations against the Chatti. There were five legions in Upper Germany. He also withdrew four legions from Britain for the war in Germania. ${ }^{43}$ These preparations suggest that Domitian took the war very seriously. Frontinus again praises Domitian for his conduct:

When the Germans, in accordance with their usual custom, kept emerging from woodland-pastures and unsuspected hiding places to attack our men, and finding a safe refuge in the depths of the forest, the Emperor Caesar Domitianus Augustus, by advancing the frontier of the empire along a stretch of one hundred and twenty miles, not only changed the nature of the war, but brought his enemies beneath his sway, by uncovering their hiding

40 Cass.Dio. LXVII 3.5

41 Tac.Agr.39.

42 Fron.Strat.I.8.

43 Ronald Syme, "Flavian Wars and Frontiers", in The Cambrige Ancient History XI, ed. by S.A.Cook, F.E.Adcock, and M.P.Charlesworth (London: Cambridge University Press, 1936), 131-88 (162-63). 
place $^{44}$

This passage reveals that Domitian had studied the misfortunes and hardships that Varus and Germanicus had encountered in their expeditions beyond the Rhine. He not only marched on the eastern side on the Rhine, but also created new territories for Rome to secure the advancements of the Roman troops. Luttwak describes Domitian's campaign as an engineering campaign. It involved construction of forts, roads, and watchtowers. It was a slow-moving offensive, not aiming to capture prisoners but to enhance the ability of the Roman troops' mobility beyond the Rhine. Its systematic nature reveals careful planning and sound strategy. ${ }^{45}$

In $\mathrm{AD} 83$ Domitian celebrated his campaign against the Chatti with a triumph. He claimed a new title Germanicus. This title appeared on official documents and coins for the period of 9 June and 28 August AD 83 first time and remained part of his official name throughout his reign. ${ }^{46} \mathrm{He}$ renamed September, the month when he became the emperor, as Germanicus. ${ }^{47}$ Syme also concludes that the campaign started and ended in AD 83. His celebration of triumph indicates Domitian had secured the victory in Germania. ${ }^{48}$

The results of the Chatti war were consequential. The region between the Taunus and the Main, the forts were established at Wiesbaden, Hofheim, Haddernheim, Okarben, and Freidberg. These forts were connected by the newly built roads for the movements of the legions. In case of an attack from the Chatti, their approach would be checked. Thus, Domitian created a new frontier on the eastern side of the Rhine. This territory was not originally belonged to the Chatti, but the Mattiaci and the Usupi tribes. However, they were friendly towards the Roman Empire. The annexation meant the protection from the warlike Chatti. ${ }^{49}$ These new limes enabled Rome to gain access to the Neuwied and fertile Wetterau. ${ }^{50}$ Besides these economic considerations, the annexed area covers the communication routes. The Hessian Gap between Taunus and Vogelsberg enabled the Roman troops easiest approach to the Wesser and the Elbe. Wetterau limes cuts off North from South Germania. It was not coincidence that defeat of the Chatti and creation of limes were followed by an advance in the south in the last years of Domitian's reigns. ${ }^{51}$

Thus, the Chatti campaign could be considered as a first step for Domitian to gain larger Roman presence in Germania region. Domitian managed to neutralize the Chatti with its campaign in $\mathrm{AD} 83$. With the newly annexed territories Domitian gained a foothold beyond the Rhine, checking the movements of the Chatti. Instead of hasty campaigns like Varus and Germanicus followed, Domitian wanted to follow a slow pacing advancement.

\footnotetext{
44 Fron.Strat.III.10.

45 Edward Luttwak, The Grand Strategy of the Roman Empire From the First Century CE to the Third (Baltimore: Johns Hopkins University Press, 1976), 103.

46 Jones, 129.

47 Suet.Dom.13.3.

48 Syme, "Flavian Wars and Frontiers", 164.

49 Syme, "Flavian Wars and Frontiers", 164-65.

50 Luttwak, 103.

51 Syme, 'Flavian Wars and Frontiers', 165.
} 
The administrative measures followed the military organization of the frontier. The conquered territories in Germania during Augustus had not been incorporated into the Roman Empire until Domitian's reign. Germania Superior and Germania Inferior (Upper and Lower Germania) were provincialized by Domitian. This was a reorganization of the territories acquired before and after Domitian's accession. The names of Upper Germania and Lower Germania appear in military documents between AD 90 and $98 .{ }^{52}$ The creation of new territories dated back to between AD 84 and 90. The victory coins of AD 84 and early $\mathrm{AD} 85$ are most likely related to the creation of new provinces. The date of the creation of provinces are most likely just after the celebration of the triumph against the Chatti because the revolt of Antonius Saturninus, the governor of Upper Germania occurred in AD 89. ${ }^{53}$

\section{The Revolt of Saturninus}

In $\mathrm{AD} 89$ the governor of Upper Germania Antonius Saturninus revolted. Two legions, Legio XIV Gemina and Legion XX, participated in the revolt. Saturninus collaborated with the Chatti. According to conspiracy, along with Saturninus' attack, the Chatti would cross the Rhine and attack the Roman troops. ${ }^{54}$ Upper Germania is an appropriate place to attack Rome and seize the capital. Vitellius had become emperor by mobilizing legions in Germania. ${ }^{55}$

Not only the authority of Domitian was under threat, but also the empire's security was in danger. The Danube army was occupied by the empire's war against the Dacian. The Parthians were supporting False Nero rebellion in Anatolia. The revolt of Saturninus brought the possibility of the civil war and incursion of the Chatti into the Roman territories. Yet, Domitian responded this crisis with a swift resolution. When he heard the news of the revolt, he left Rome with his Praetorian Guards. He ordered Trajan to march from Spain to Germania with Legio VII Gemina, the governor of Upper Germania Lappius Maximus to mobilize his legion, and procurator of Raetia to bring his cohorts. If the governors of Britannia and Upper Germania had joined the conspiracy, Domitian would have fallen back to the Danube to prepare a prolonged civil war. ${ }^{56}$ The main determinant factor in the suppression of the revolts was that the position of Lappius Maximus. He remained loyal to Domitian suppressed the revolt by defeating Saturninus despite facing outnumbered by him. Thus, he saved Domitian and the empire. ${ }^{57} \mathrm{On}$ the day of the battle the Chatti appeared but thaw in the river prevented them from crossing. ${ }^{58}$ When Trajan and Domitian arrived, the revolt had been crushed thanks to Lappius Maximus.

52 Reinhard Wolters, "Emergence of the Provinces", in The Oxford Handbook of The Archaeology of Roman Germany, ed. by Simon James and Stefan Kirmnicek (Oxford University Press, 2020).

53 Southern, 90-91.

54 Jones, 30.

55 Southern, 101.

56 John Karl Evans, "Senatorial History and The Principate of Domitian" (McMaster University, 1974), 94-95.

57 Syme, 'Flavian Wars and Frontiers', 173-74.

58 Suet.Dom.6.2. 
Cassius Dio claims that Lappius Maximus burnt the letters that implicate coconspirators. ${ }^{59}$ Syme argues that there was no indication to show that Lappius Maximus was a traitor to Domitian. ${ }^{60}$ After suppressing the revolt Lappius Maximus was tasked to punish the Chatti, who supported the revolt of Saturninus. The Chatti destroyed the watchtowers between the Lahn and the Taunus, and damaged the forts located between Okarben, Heddernheim, and Hofheim. Lappius Maximus expelled the Chatti and a treaty was arranged with them. Domitian had celebrated a double triumph over the Chatti and the Dacians in AD 89-90. ${ }^{61}$

The measures taken after the Chatti war in AD 85 seemed to work for Domitian. The buffer zone arranged by Domitian beyond the Rhine led the Chatti deal with the Roman forts before crossing the Rhine. When the revolt had been suppressed, the road networks built by Domitian enabled Lappius Maximus to punish the Chatti. Furthermore, the rearrangement of provinces as Upper Germania and Lower Germania led these governors to check each other's power. When the governor of Upper Germania revolted, the governor of Lower Germania suppressed it. The role of Legio I Minervia created by Domitian himself was critical in defeating Saturninus. Legio I Minervia, Legion VI Victrix, Legio XII Primigenia Legio X Gemina and auxiliary troops, and the Rhine fleet were awarded with the title Pia Fidelis Domitiana. Maximus was awarded with consulship. ${ }^{62}$ Domitian also took some precautions. Domitian abolished double camps for legions and also limited the sum of money that the legions could keep at their headquarters. Legio XIV Gemina remained in Mainz but its treasonous partner Legio XXI Rapax were moved to Pannonia. ${ }^{63}$

Syme and Jones argue that the revolt did not have senatorial connections and it was a spontaneous event. ${ }^{64}$ On the other hand, Evans reports that Saturninus revolt was the instrument of a greater conspiracy. News of the revolt reached Rome before it took place. Domitian mobilized his Praetorian Guards within eleven days. Even though Cassius Dio reports that, Lappius Maximus burnt the letters that contained the list of conspirators, Domitian unleashed his wrath. The governor of Britain, Sallustius Lucullus was executed. ${ }^{65}$ The executions of the senators in Rome such as C. Vettulenus Civica Cerialis were most probably related with Saturninus revolt. ${ }^{66}$

Even Jones acknowledges the lack of reasons for the revolt. The wage of the soldiers had been increased five years ago and their privileges were recognized. Domitian was popular among the troops. Pressure, therefore, must have emanated from above rather than from below. ${ }^{67}$ The dissatisfied elements in Rome must have sought Saturninus and the hostile tribes in Germania to overthrow Domitian. It was not only a treason against the

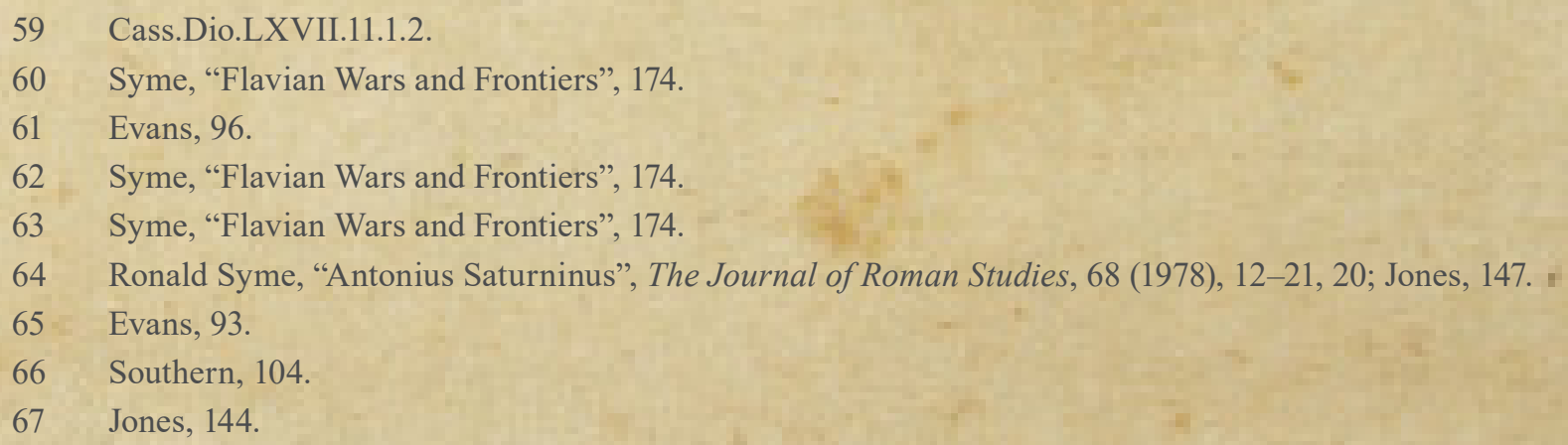


emperor but also it was a treason against the empire. They risked the invasion of the Chatti due to their enmity towards Domitian. These factors must have led Domitian to consider rooting German problem permanently.

\section{Domitian's Marcomanni and Quadi Wars}

The chronology of the war against the Suebi, consisted of the Marcomanni and the Quadi, is interesting. When the Marcomanni and the Quadi refused to help Domitian in his war against the Dacia, Domitian declared war against those tribes. However, at the initial stage the war did not go well. To respond this threat, Domitian made a peace with Decebalus, the king of the Dacians, having been defeated by the Roman legions. Domitian placed a diadem on the of head of Diegis, the brother of Decebalus, which signified that Dacia had been reduced to the status of the client kingdom of the Roman Empire. ${ }^{68}$ This narration suggests that Domitian wanted a war against the Suebi by using their refusal to help him in his campaign in Dacia. After defeating Decebalus, Domitian subdued Dacia, but did not annex it. Fuscus, who was defeated and killed by the Dacians were revenged and the Dacians took the Roman yoke. ${ }^{69}$ Domitian shifted his focus to deal with the Marcomanni and the Quadi, which he considers much more threat for Rome.

There was a justification of Domitian's decision. It was not just a response to the affront against the emperor of Rome. No Flavian emperor was willing to take a risk of war if this war could be avoided. Domitian's attack aimed to forestall the aggression of the Marcomanni and the Quadi and to prevent the greater danger. The Iazyges allied themselves with their German neighbors. Thus, a coalition of the Suebi and the Sarmatian Iazyges were formed against Rome. ${ }^{70}$

The Suebian Marcomanni and Quadi had fickle loyalty. They had remained defiant against the conquest of Drusus and Tiberius. Yet, they wanted to avoid the Romans by migrating to different region. Sometimes they acted as suppliants for the Roman Army. However, their increased capability must have been seen as a threat by Tiberius, so he attacked the Marcomanni. ${ }^{71}$ During his emperorship, Tiberius also employed diplomatic measures to pacify the Marcomanni, by supporting rivals against the tribe's charismatic and powerful king Maroboduus. Finally, he had become a refugee in Rome. ${ }^{72}$ As an enthusiastic reviewer of Tiberius' life and his letters, ${ }^{73}$ Domitian must have learned the level of threat and measures that should be taken against the Marcomanni from Tiberius.

The Sarmatians were considered as much more threat than the Suebi. In the year of the four emperors, when the Flavian generals marched against Vitellius, The Sarmatian Iazyges offered their service to the Flavian generals, but the Flavian generals refused their help,

68 Cass.Dio.LXVII.7.

69 Martial.Epig. VI.LXXVI.

70 Syme, "Flavian Wars and Frontiers", 176.

71 Vell.Pat.II.108-109.

72 Vell.Pat.II.129.

73 Suet.Dom.20.1. 
fearing that they might change sides during the war. ${ }^{74}$ Vespasian vigorously strengthened the defenses on the Danube. The camp of Legio XV Apollinaris, stationed at Carnuntum, was reorganized and an auxiliary fort at Aquincum (where Danube could be passed) was set up directly opposite to the region occupied by Iazyges. A chain of forts at Hurlec, Leskovec, Donji Milanovac Nikopol, Adony, and Orehovo were established by Vespasian. Domitian continued Vespasian's policy. In addition to land forts, Domitian set up naval bases at Zemun, Noviodunum, Arcar, and Sexaginta Prista. The Roman fleet were placed on the Danube. ${ }^{75}$ This evidence demonstrates that instead of a hasty war against the Suebi and the Sarmatians, Domitian's campaign on the Upper Danube was a calculated war. After pacifying Lower Danube by subduing the Dacians, Domitian must have thought that it was time to deal with troublesome tribes in Germania and Pannonia.

The military side of the conflict is almost unknown. The Iazyges crossed the river and annihilated a legion. ${ }^{76}$ The modern historians have a consensus that this legion was the rebellious Legio XXI Rapax. ${ }^{77}$ Domitian could not have been too upset of the destruction of this seditious and treasonous legion. After the defeat, however, he personally visited the front. Until his return in January AD 93, he spent eight months in a campaign. ${ }^{78} \mathrm{He}$ recovered the damage and assumed a salutation even though a servile senate was ready to award a triumph. ${ }^{79}$

Domitian's refusal of celebrating triumph deserves an inquiry. Suetonius states that after his victory over the Sarmatians, Domitian was merely content to offer laurels to the Temple of Jupiter ${ }^{80}$ Although Martial states that the act of placing laurels are equal of the celebration of triumphs, ${ }^{81}$ it still was not a formal triumph. Domitian's merciful treatment is demonstrated as a possible explanation of this attitude by Statius. ${ }^{82}$ Yet, the reasons must be more complex than that. The disturbance in Rome among opposition circles or Domitian's dissatisfaction of the result and his desire to renew the war could be the plausible reasons. ${ }^{83}$ Instead of domestic reasons, Domitian must have thought to bid his time and strengthened his position on the Danube after neutralizing an immediate threat.

Besides military preparations, Domitian implemented a series of diplomatic measures. The Lygians in Moesia asked assistance for their war against the Suebi. Domitian sent a hundred strong knights. Masyus, the king of the Semnones tribe, and Ganna, a virgin seeress who held enormous respect among German tribes, were invited to Rome and honored. ${ }^{84}$

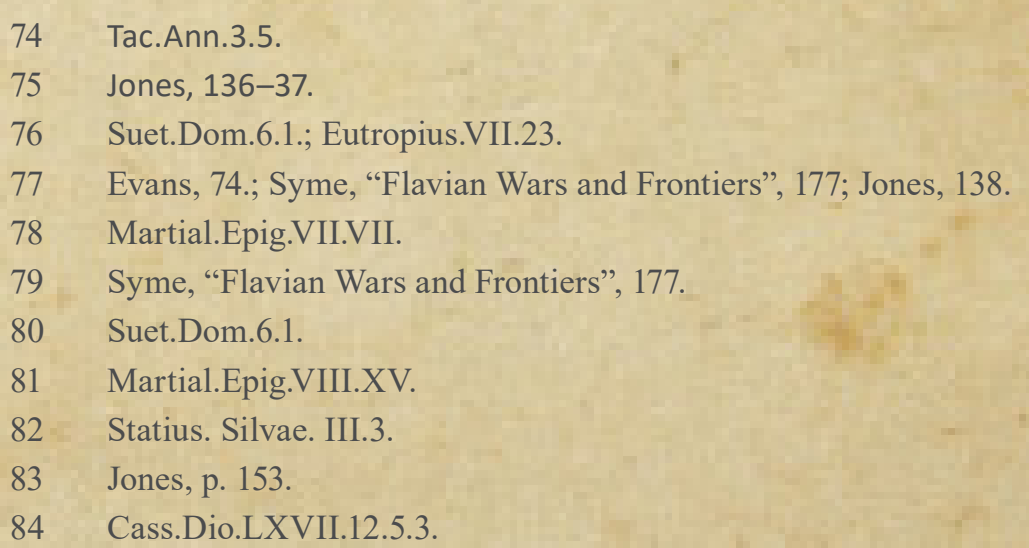


The Lygians were large tribe, that participated in Maroboduus' Marcomanni led coalition. ${ }^{85}$ They preserved their power and lived in several areas in Silesia. ${ }^{86}$ The Semnones, on the other hand, were the noblest and oldest Germanic tribes. They lived in several cantons and claimed supremacy over the Suebi. ${ }^{87}$ These diplomatic moves aimed to isolate the Marcomanni and the Quadi in Germania while proving a base for the Roman troops in Central Europe. While choosing his allies, Domitian considered the nobility and strength among German tribes.

\section{A Planned Offensive in Germania}

In addition to the extensive diplomatic contacts with the powerful tribes in Germania and Pannonia, there are indications that Domitian had been preparing a massive offensive that would have been the biggest expansion of the Roman Empire since Augustus era. Domitian had been planning a pincer movement, which would grasp the region between southern Germania and northern Pannonia. Domitian slowly annexed the southern Germania territories. The annexation covered the territories previously annexed after the Chatti campaign. The Roman advance followed south of Neckar, on Mainz-HeidelbergStuttgart-Ulm, providing a shorter route for the Roman troops between the Rhine and the Danube. Domitian proceeded the plain of the Rhine in the middle of Neckar and from the Danube northwards and north-eastwards. In the last years of his reign, Domitian pushed the eastern forts of Raetia to the ultimate line of the frontier. East Raetian forts were stretched as far as embracing the forts Oberdorf, Munningen, Gnootzheim, and Weissenburg. The establishment of forts along the Neckar from Wimpfen to Cannstatt and Könge were complementary for the moving of Raetia frontier. Furthermore, a series of forts were set up on the Alb-Limes and the Neckar. By the end of Domitian's rule, the Roman Army had a chain of forts in southern Germany. ${ }^{88}$ 


\section{Figure 1: Expansion of Roman Frontier in Germania}
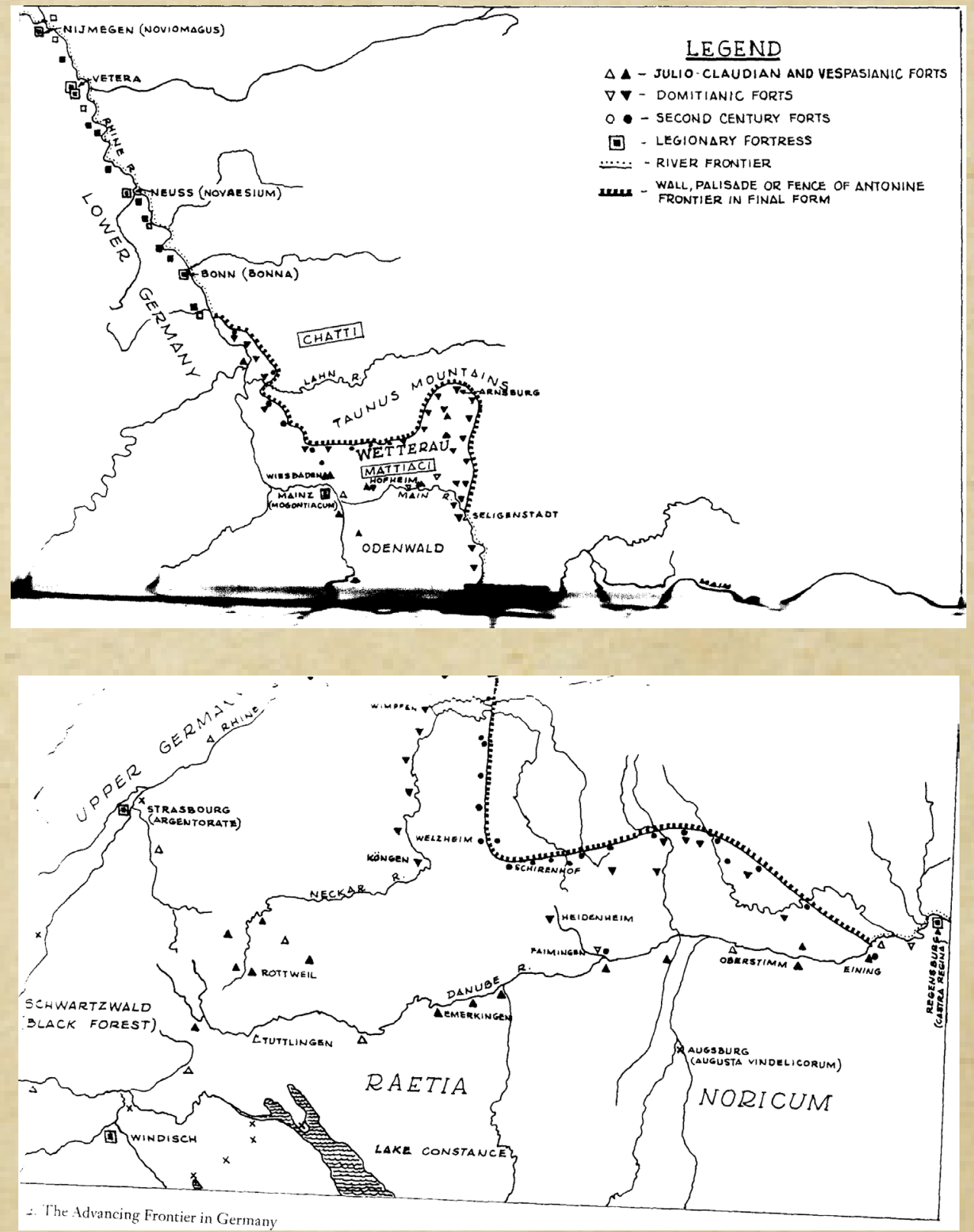

Source: Luttwak, 1976, p. 108

Another indication was the concentration of forces in Pannonia and the distribution of the posts in the region. The legions in Upper Moesia and Pannonia increased since AD 90s. There were five legions in Pannonia. ${ }^{89}$ Five legions were already formed in Upper Moesia. ${ }^{90}$ In Lower

89 Jones, 155.

90 Ronald Syme, "Rhine and Danube Legions under Domitian, The Journal of Roman Studies, 18 (1928), 41-55, 47. 
Moesia there were two legions, which could be mobilized immediately. Besides the legions, numerous auxiliaries existed in Upper Moesia. The temporary transfer of the legions from Pannonia to Upper Moesia was a common practice during Domitian's rule. This indicates a close cooperation between two provinces. Until recently, this military concentration was thought be a part of Trajan's Dacian war. However, it is revealed that most of these forces were already present in the region before Domitian's death. ${ }^{91}$ It will be safe to assume that the legions located in Moesia would also support an offensive. Future emperors such as Trajan and Hadrian were moved to Pannonia for administrative and military posts just before Domitian's death. Pompeius Longinus, who was a consul in AD 90 was appointed as the governor of Upper Moesia ${ }^{92}$ This suggests Domitian chose his talented generals and military officials for his planned offensive.

\section{Figure 2: Placement of Roman Legions on Danube}

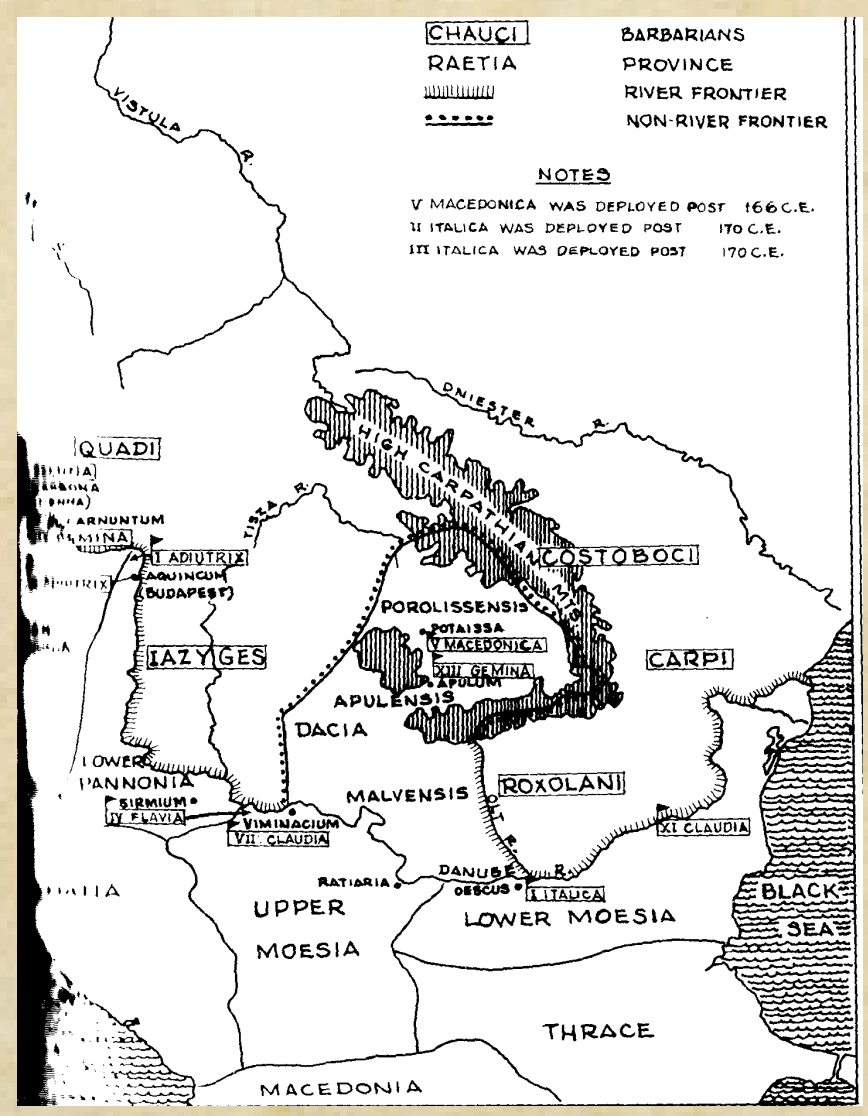

Source: Luttwak, 1976, p. 113.

These military developments in Pannonia should be evaluated in context of the Roman annexations and frontier policies in the southern Germania. Rome dominated the southern Germania. This would have enabled the Roman empire to approach the Marcomanni from the west. In the north, the Suebic tribes and the Lygians were convinced against the Marcomanni and the Quadi. Decebalus was neutralized and made an ally against the 
Sarmatians. This was a perfect encirclement. It would have been a pincer movement to conquer the Marcomanni and the Quadi while also neutralizing the Sarmatian Iazyges. The legions located in Upper Germania and Lower Germania would have been used if Domitian had had lived enough to realize his plans.

\section{The Campaigns after the death of Domitian}

Domitian was assassinated on 18 September 96 by Stephanus, the steward of Domitian's condemned cousin Domitilla, Parthenius, the chamberlain of Domitian, Maximus, a freedman of Parthenius, Clodians, a court official, Satur, another official, and a gladiator. ${ }^{93}$ Uncharismatic and low-profiled Nerva was his successor. The army in Pannonia campaigned against the Suebi and sent laurels to Rome in autumn $97 .{ }^{94}$ The concentration of the army and senators moved from foreign affairs to domestic affairs mainly who would succeed senile Nerva. Rome witnessed the revolt of Praetorian Guard led by Casperius Aelianus at the anniversary of Domitian's death. Nerva was taken hostage and forced to punish Domitian's murderers. ${ }^{95}$ Nerva adopted Trajan, a Domitian loyalist general as his successor. ${ }^{96}$ That was a mild coup that effectively ended Nerva's rule de facto. Fortunately, Nerva died soon so his rule also ended de jure without an internal conflict.

Although Trajan was an effective general, who took part in Domitian's many campaigns, he lacked strategic vision of the assassinated emperor. Instead of focusing on troublesome Germanic tribes, he turned to the already defeated Dacians for a cheap victory to increase his popularity. The official reason was to repair Roman honor damaged by Domitian's previous peace treaty. After series of difficult wars, he managed to defeat the Dacians by AD 106 and brought Decebalus' head to Rome. The territory of Dacia was annexed to the Roman Empire. Then he started a campaign against the Parthians. ${ }^{97}$ Cassius Dio's report of repairing Roman honor as a cause of the Dacian war testifies the absence of the strategy from this campaign. Without strengthening defense of the newly acquired territories Trajan rushed to the Parthian campaign. Weak defenses and the lack of Roman troops led to the Marcomanni invasion in the subsequent century. ${ }^{98}$ Hadrian, the successor of Trajan, considered abandoning Dacia completely, but he only destroyed the bridge to cross the Danube that Trajan had built. ${ }^{99}$ Had he lived, Domitian would not have bothered to deal with Decebalus but he would have diverted the empire's resources to conquer the large part of Germania.

\footnotetext{
93 Suet.Dom.17.

94 Andrew Berriman, Malcolm Todd, and Malcom Todd, "A Very Roman Coup: The Hidden War of Imperial Succession, AD 96-98”, Historia: Zeitschrift Für Alte Geschichte, 50.2 (2001), 312-331, 316.

95 Pliny. Pan.6.1.

96 Cass.Dio.LXVIII.3.4.

97 Cass.Dio.LXVIII.6.-14.

98 C. R. Whittaker, Rome and Its Frontiers: The Dynamics of Empire (London and New York: Routledge, 2004), 34-35.

99 Everett L. Wheeler, "Rome's Dacian Wars: Domitian, Trajan, and the Strategy on the Danube, Part II", The Journal of Military History, January.75 (2011), 191-219, 215.
} 
Domitian's long-term strategic thinking proved correct in the next century. While the Roman Empire was at war with the Parthians in AD 166, the Marcomanni attacked the Roman Empire. ${ }^{100}$ The situation was so dreadful for the Romans that the emperor Marcus Aurelius summoned priests from every religion in the Roman Empire to perform the rites for the well-being of the empire. Even the invasion of Italy was expected. ${ }^{101}$ The Quadi also asked for peace, distancing themselves from the Marcomanni. ${ }^{102}$ Yet, the Marcomanni were successful in many battles against the Roman Empire. ${ }^{103}$ The Quadi proved to be deceitful and joined forces with the Iazyges against the Romans. ${ }^{104} \mathrm{He}$ managed to repel the Marcomanni while they were trying to cross the Danube by employing German mercenaries. ${ }^{105} \mathrm{He}$ had to make agreement with the Iazyges because of the revolt of Avidius Cassius. ${ }^{106}$ Although the Romans gained the upper hand against the Marcomanni and the Quadi, his successor Commudus, chose to make an agreement with the Marcomanni. ${ }^{107}$ Thus, the Marcomanni and the Quadi problem stood still for the Roman Empire.

\section{Conclusion}

Although his accomplishments in Germania have been undervalued by senatorial historians, Domitian was very successful in his Germania policy. He correctly identified that the Chatti had been preparing an attack against the Roman Empire and then he subdued them in $\mathrm{AD} 85$. He took the name of Germanicus rightfully and used it in official documents. He renamed September, the month when the ascended the throne, as Germanicus. This shows his emphasis on the region.

Although he was preoccupied with the Dacian incursions, he saw the bigger picture by allowing Decebalus to remain as the king of the Dacians after humbling him. Instead, he mobilized the empire's resources for his war against the Marcomanni, the Quadi, and the Sarmatians. The initial engagement was unsuccessful for the Romans, but when Domitian went to the region personally, the defeat was reversed. Domitian, then, employed diplomatic and military measures to encircle those tribes, knowing that a success in Germania required a careful planning and massive resources. Therefore, only after the extensive diplomatic and military moves the Roman offensive would have been possible. Yet, this massive offensive never occurred because he was assassinated in AD 96.

Domitian's successors lacked his strategic vision. Nerva was a weak ruler, whose legitimacy was challenged by the troops, who loved Domitian. Trajan, Domitian's loyal general, preferred an easy victory against the Dacians, which carried little strategic value. Domitian's long-term strategic vision was confirmed in the middle of the second century

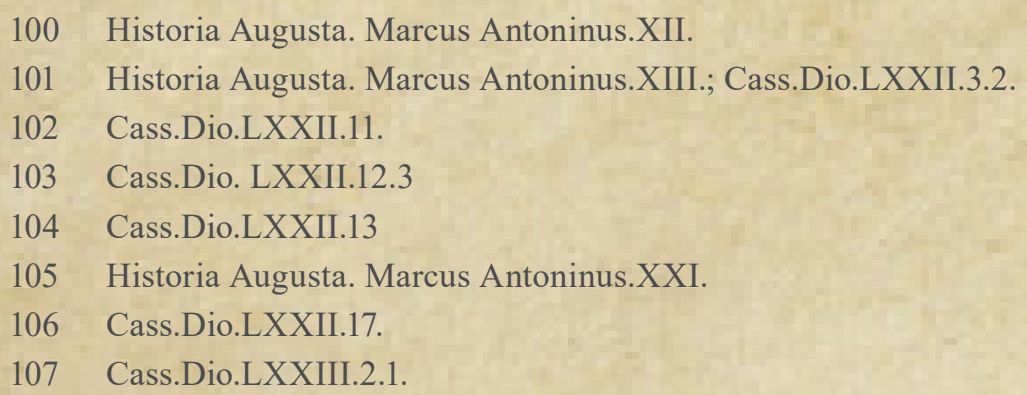

100 Historia Augusta. Marcus Antoninus.XII.

101 Historia Augusta. Marcus Antoninus.XIII.; Cass.Dio.LXXII.3.2.

102 Cass.Dio.LXXII.11.

103 Cass.Dio. LXXII.12.3

104 Cass.Dio.LXXII.13

105 Historia Augusta. Marcus Antoninus.XXI.

106 Cass.Dio.LXXII.17.

107 Cass.Dio.LXXIII.2.1 
when the Romans had to deal with the Marcomanni, the Quadi, and the Sarmatians coalition. Marcus Aurelius and Commudus failed to resolve this issue for the Romans. If Domitian had had lived enough, he was ready to resolve this issue. The landscape of Central Europe could have been different if the Romans had conquered the territory as Domitian had planned.

\section{BIBLIOGRAPHY}

Berriman, Andrew, Malcolm Todd, and Malcom-Todd. (2001). "A Very Roman Coup: The Hidden War of Imperial Succession, AD 96-98”, Historia: Zeitschrift Für Alte Geschichte, $50.2,312-31$.

Cassius Dio (1955). Roman History, Volume VIII, Books LXI-LXX (Earnest Cray, transl.). William Heinemann Ltd. and G. P. Putnam's Sons: London and Massachusetts.

Cassius Dio (1957) Roman History, Volume IX, Books LXXI-LXXX (Earnest Cray, transl.). William Heinemann Ltd. and G. P. Putnam's Sons: London and Massachusetts.

Evans, John Karl. (1974). ‘Senatorial History and The Principate of Domitian’ (McMaster University.

Jones, Brian. (1992). The Emperor Domitian (London and New York: Routledge.

Historia Augusta. (1991), David Magie, transl. Harvard University Press: Massachusetts.

Levick, Barbara. (1990). Claudius (London: B. T. Batsford Ltd).

Levick, Barbara. (1999). Tiberius The Politician (New York: Routledge).

Luttwak, Edward. (1976). The Grand Strategy of the Roman Empire From the First Century CE to the Third (Baltimore: Johns Hopkins University Press).

Martial. (1947). Martial: Epigrams I, Books I-VII (Walter C. A. Kerr, transl.). William Heinemann and G. P. Putnam's Sons: London and Massachusetts.

Martial. (1947). Martial: Epigrams II, Books VIII-VII (Walter C. A. Kerr, transl.). William Heinemann and G. P. Putnam's Sons: London and Massachusetts.

Seager, Robert. (2005). Tiberius (Malden: Blackwell Publishing).

Shotter, David. (2004) Tiberius Caesar (London and New York: Routledge).

Southern, Pat. (1997). Domitian the Tragic Tyrant (Oxon: Routledge).

Suetonius. (1959). The Lives of the Caesars Volume 1 (John C. Rolfe, transl.). William Heinemann Ltd. and Harvard University Press: London and Massachusetts.

Suetonius. (1959). The Lives of the Caesars. Volume II (John C. Rolfe, transl.). William Heinemann Ltd. and Harvard University Press: London and Massachusetts.

Statius. (1928). Silvae. (J. H. Mosley, transl.) William Heinemann Ltd. and Harvard University Press: London and Massachusetts.

Strabo. (1954). The Geography of Strabo. (Horace Leonard Jones, transl.) William Heinemann Ltd. and Harvard University Press: London and Massachusetts. 
Syme, Ronald. (1978). “Antonius Saturninus”, The Journal of Roman Studies, 68, 12-21.

Syme, Ronald. (1936). "Flavian Wars and Frontiers", in The Cambrige Ancient History $X I$, ed. by S.A.Cook, F.E.Adcock, and M.P.Charlesworth (London: Cambridge University Press), 131-88.

Syme, Ronald. (1928). "Rhine and Danube Legions under Domitian", The Journal of Roman Studies, 18 , 41-55.

Tacitus. (1999). Agricola and Germania (A.R.Birley, transl.). Oxford University Press: Oxford.

Tacitus. (2004). The Annals. (A. J. Woodman, transl.). Hackett Pub Co Inc.: Indianapolis. Velleius Paterculus. (1961), Compendium of Roman History, (Frederick W. Shipley, transl.) William Heinemann Ltd., London, Harvard University Press, Cambridge, Massachusetts. Wells, Peter S. (2003). The Battle That Stopped Rome (New York and London: W. W. Norton \& Company).

Wheeler, Everett L. (2011). 'Rome's Dacian Wars: Domitian, Trajan, and the Strategy on the Danube, Part II', The Journal of Military History, January.75, 191-219.

Whittaker, C. R. (2004). Rome and Its Frontiers: The Dynamics of Empire (London and New York: Routledge).

Winterling, Aloys, Caligula: A Biography. (2011). (Berkeley Los Angeles London: University of California Press).

Wolters, Reinhard. (2020). "Emergence of the Provinces', in The Oxford Handbook of The Archaeology of Roman Germany, ed. by Simon James and Stefan Krmnicek (Oxford University Press. 